バルブ鋼の 研究

$\sigma$ 相析出硬化型ハルフ鋼について（其の 2 ）

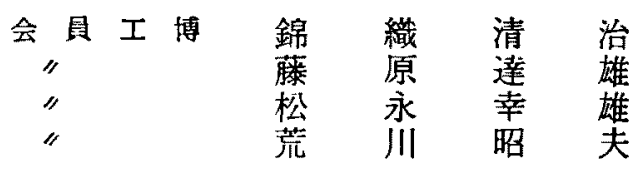

\section{9. 熱間抗張試検}

平行部の直佳 $6 \mathrm{~mm}$ 带さ $40 \mathrm{~mm}$ なる引張試倹 片を作り $1,000^{\circ} \mathrm{C} \times 15$ 分空冷後 $780^{\circ} \mathrm{C} \times 15$ 時閏 の時効を施し常温 $\left(30^{\circ} \mathrm{C}\right), 500,600,700,800$, $900^{\circ} \mathrm{C}$ の各温度で弓張武娩を行つた。第 5 图注 其の結果を示す。售鋼種Cは $700^{\circ} \mathrm{C}$ のみ行つ た。

第5图 各鼬度におりる機械的烧算

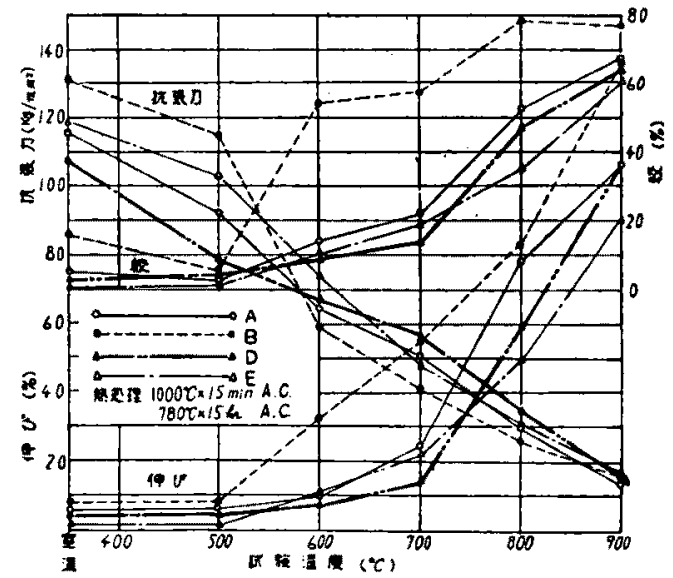

抗張力は $500^{\circ} \mathrm{C}$ 迄は $\mathrm{B}>\mathrm{E}>\mathrm{A}>\mathrm{D}$ で常温と 大差なく，600 $\mathrm{C}$ 以上になると各鋼種共一様に 低下を示し $700^{\circ} \mathrm{C}$ では $\mathrm{D}>\mathrm{A}>\mathrm{E}>\mathrm{B}>\mathrm{C}$, $800 \mathrm{C}^{\circ}$ では $\mathrm{D}>\mathrm{E}>\mathrm{A}>\mathrm{B}$ で低温の場合に比較 して強度順位は逆になる。向路種 $\mathrm{C} の 700^{\circ} \mathrm{C}$ に 於ける抗張力は $41.4 \mathrm{~kg} / \mathrm{mm}$ こである。

伸び絞りは各鋼種共 $500^{\circ} \mathrm{C}$ 以下では非常に低 いが温度上昇上共に堌加し，鎆種 $\mathrm{B} は 600^{\circ} \mathrm{C}$ 上 り稍々顕㬐な増加を示すが其の他の鋼種は 800 ${ }^{\circ} \mathrm{C}$ 至つて急激な增加を示す。

\section{7. 衡慗試䀧}

(1) シャルピー値と時効時間

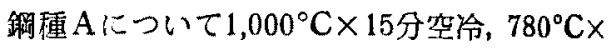
$5,10,15$ 時閒時效処理したものについて常温に 第 6 図 熱処時勃特間之衝 於ける衝撃試験? 慗值との関保

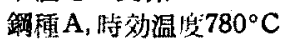
武料仕すべて焼入 $\left(1,000^{\circ} \mathrm{C}\right.$ 其の結果を示す. $\left.\times 15^{\prime} \mathrm{A}, \mathrm{C}\right)$ せる屯の この鋼蝩のシャル

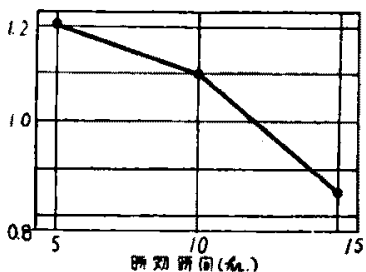
ピー值は極めて低 く 5 時間時效て $1.2 \mathrm{kgm} / \mathrm{cm}^{2}$ であ りこれは更に時効 時間が長くなると 共に, 即占 $\sigma$ 生成

量が增すにつれて漸炏低下する。

(2) 㪇閪重撃試験

$1000^{\circ} \mathrm{C} \times 15$ 分空冷 $780^{\circ} \mathrm{C} \times 15$ 時間時効を行 つた鎆種Aについて $400 \sim 900^{\circ} \mathrm{C}$ の試験温度て

第 7 図熱間薄 慗值

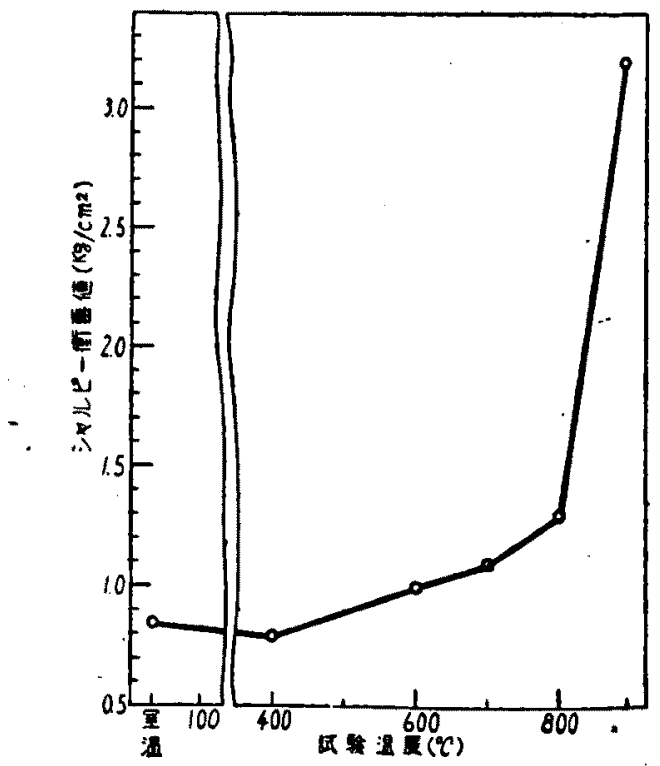


熱間衝撃武験を行つた結果を第7図に示す。

$400^{\circ} \mathrm{C}$ では常温と大考なく，600 $\mathrm{C}$ 以上にな ると温度上昇と共にシャルピー值も濑次上韭を

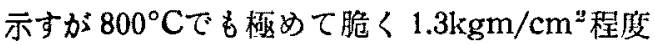
に過ざない，然し $900^{\circ} \mathrm{C}$ になると $\sigma$ が再溶解す ろので念激に靬性は増加する。

\section{8. 酸 化 試 験}

$1000^{\circ} \mathrm{C} \times 15$ 分空冷処理した武料について 800 , $1000,1200^{\circ} \mathrm{C}$ 各温度で 5 時間宛 4 回の繰返加 熱党行い酸化增量を測定した，向加熱雲囲気は 空気中である。第 8 图に测定結果を示す。

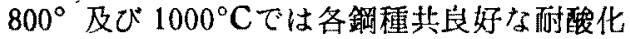


り $1000^{\circ} \mathrm{C}$ では鋼種 $\mathrm{A}, \mathrm{D}$ が稍々優れ，鋼係 $\mathrm{C}$ が秒少つている， $1200^{\circ} \mathrm{C}$ では何れも酸化甚し く特に低 $\mathrm{Cr}$ の銅種 $\mathrm{B}, \mathrm{C}$ 及び含 $\mathrm{V}, \mathrm{N}$ の鋼䅖 $\mathrm{E}$ が著しく20時間の加熱で全部スケールになり崩 解した。

この結果から酸化増量を $\mathrm{Cr}$ 量との関係をと ると第 9 図の如く，酸化增量か $\mathrm{Cr}$ 量之共に規 則的に減少する事が明らか比かる。唯鋼種 $\mathrm{E}$ がこの規則性から外れるがてれは恐らく まれているVの影響と考えている。

\section{9. バルブ成形試䀦}

各鋼種の $10.7 \mathrm{~mm} \phi$ 糸材について富士バルブ K. K に於て自動車エンジン用排気弁を試作し 製造上の難易性について誠查した結果は下記の 通りである。

（1）鈠 造 性

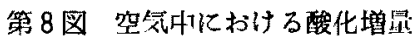
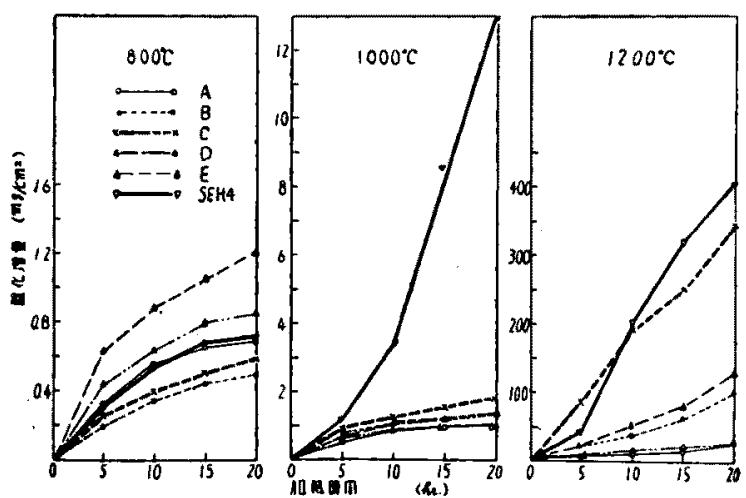

第9図 $\mathrm{Cr}$ 星と酸化增量乞の関係



バルブ䏑部のアプセット鍛造性は各鋼種共 $\mathrm{SEH} 4$ よりは容易であり, SEH 3 と略々同程度 で良好である。

(2) 機械加工性

鈠造後シエーパー加工を行つたがこの加工性

第10図 成形バルフの硬度分布

(封效：釷造后740 $780^{\circ} \mathrm{C} \times 15 \mathrm{hr}$. 断続時効后)

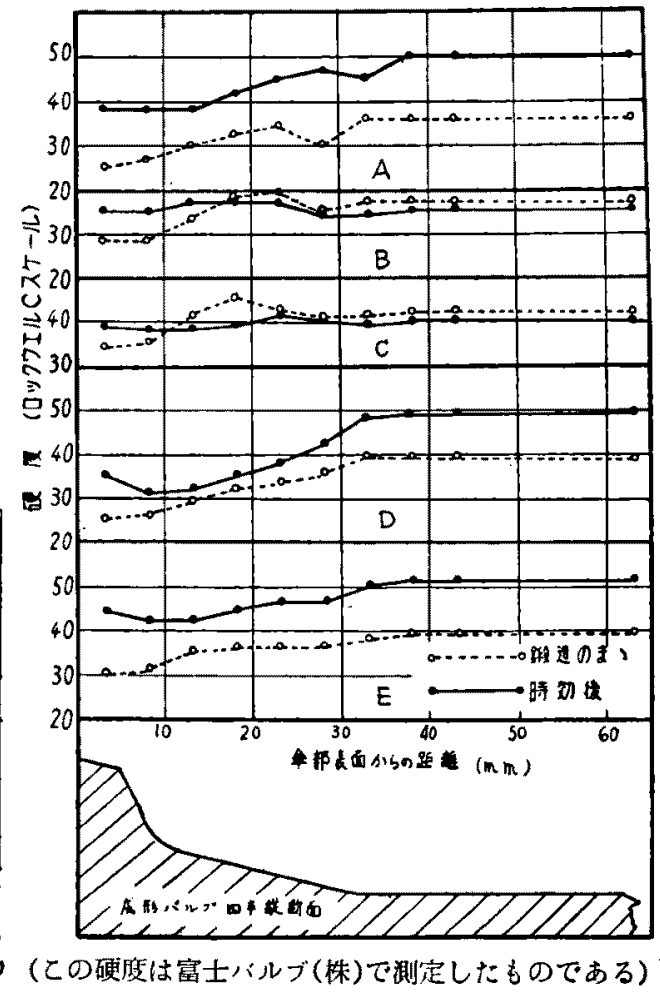


第11図再些処理後の成形バンプ硬废分布

始人： $740 \sim 780^{\circ} \mathrm{C} \times 15 \mathrm{hr}$ 断繥時效しだ゙ルブを $1000^{\circ} \mathrm{C} \times 15^{\prime} \mathrm{A}, \mathrm{C}$ 時效：上郡の煤入を行らた武料学 $780^{\circ} \mathrm{C} \cdot 15 \mathrm{hr}$ 遇続加熱

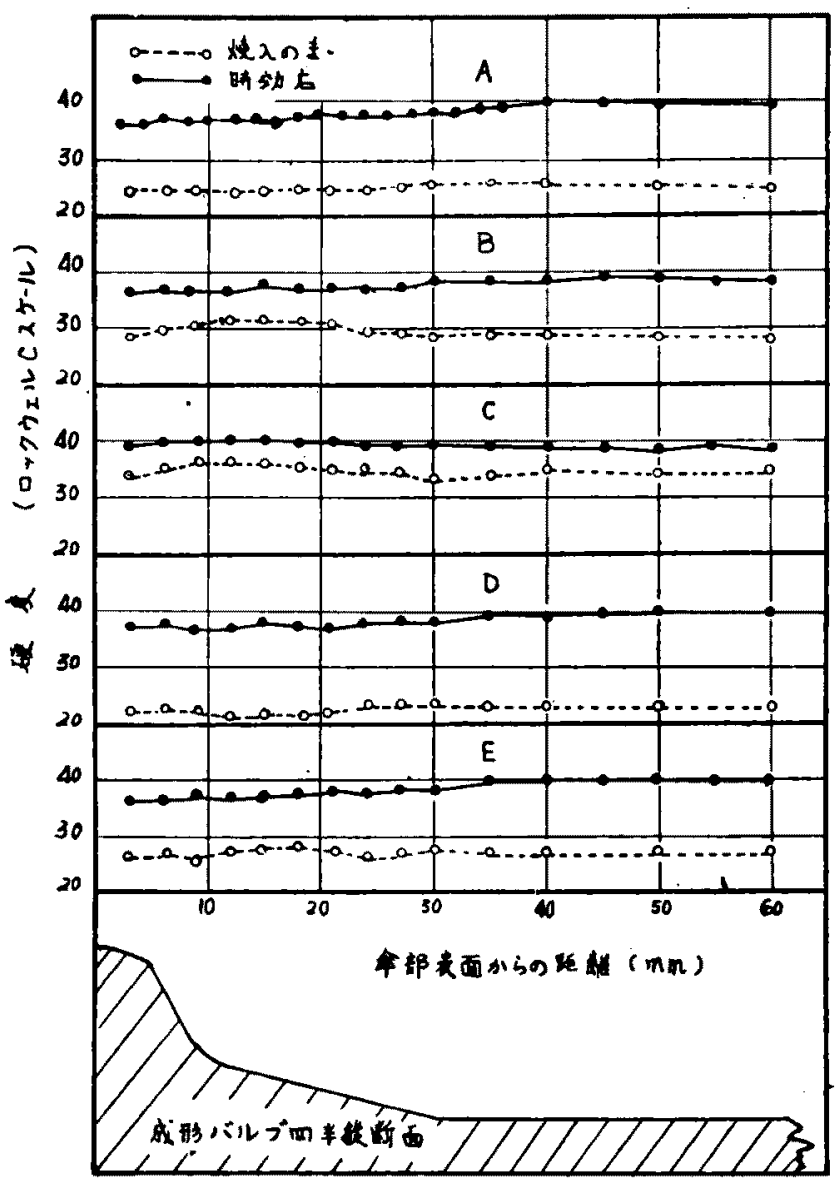

はD (易) $>\mathrm{A}>\mathrm{E}>\mathrm{C}>\mathrm{B}$ (難) で一般に低

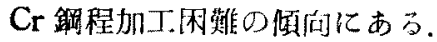

(3) 硬度行布


$\times 15$ 時間（繰这し延15㭙閒）時郊後の硬度分们 を第10図に示守。

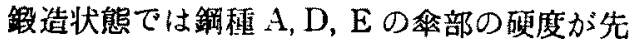
端に行くに従い平行部に比し漸次低下してい

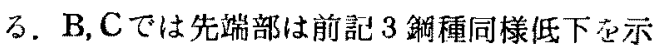
しているが先端より約 $20 \mathrm{~mm}$ 近くの位置では平 行部よりも高い硬度のピークが示されている。

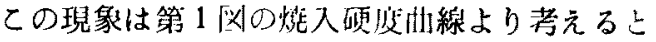
番部先端はアブセツト加熱により 1050ー1100 ${ }^{\circ} \mathrm{C}$ の高温焼入を喾けたととによる硬度低下で $\mathrm{B}, \mathrm{C}$ の硬度ビークは恐らく $950 \mathrm{C}$ 附近の温度 万。
に相当した部分心烧入效果と考えら れる。

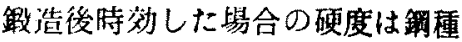
$\mathrm{A}, \mathrm{D}, \mathrm{E}$ は銭造状態の硬度曲線と平 行して RC 利10－15 高くなつてい 万か;， B，Cは部と平行部の硬度差 が多んどなく兆行部は時効により反 つて便度低下を示している。

龬種 $\mathrm{A}, \mathrm{D}, \mathrm{E}$ の硬度堌加は $\alpha \rightarrow \sigma$ 生成によるもので策部の硬度が銭造 状態に平行して低いのは恐らく高温 加熱による $\alpha$ 相娍少の影望による ものと思われる、又平行部の硬度が $1000^{\circ} \mathrm{C} \times 15$ 分空冷後 $780^{\circ} \mathrm{C} \times 15$ 時 間理続時效したものに比し RC 約 5

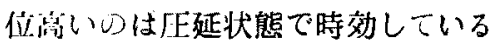
事及び断続時效空行つている事，時 效鼬度が780 $\mathrm{C}$ より稍々低い事等に 影望されているものと思われる，合 これ学確諗する為に後述(5)項に示す 如き実験を行つた。

鎆種 $\mathrm{B}, \mathrm{C}$ は長時間焼學により平 行部の硬度は焼矢軟化により低下 し，久アブセット加熱潒受けた英部 は宸化物の析出及びオーステナィト のマルテレサイト化による二次硬化 現象により硬度上昇を示している。

又とれらの闰一試料学再焼入 $\left(1000^{\circ} \mathrm{C} \times 15\right.$ 分 空冷) 後時効 $\left(780^{\circ} \mathrm{C} \times 15\right.$ 時間拈続）した場合 の硬度曲線を第11図に示す。

再焼入後時效迈理により第10図に示された萃


$\mathrm{A}, \mathrm{D}, \mathrm{E}$ の硬度均一性は著しく良くなつてい

\section{(4) 組 織}

成形後 $740 \sim 780^{\circ} \mathrm{C}$ で延15時間断続時効した 場合の各鉿程の㩆微鏡組織を钼察した。

平行部は们れもフアイバー組織を示し $A, D$, Eにのみ $\sigma$ の析出が諗められるが，粒が稍緇 く $\sigma$ 粒間の距離が近い，との部分の硬度が高い のはとのような組織によるものである。. 
傘部にはファイバーは諗められず且平行部よ り粗い組織を示している。 $\sigma$ 生成量は鋼種 A. Dは梢少なく，Eは著しく少なくなつている. 又 $\sigma$ 粒も大きく $\sigma$ 粒間の距離も大となつてい る.との部分は時効前にアプセットの際 $1050^{\circ} \mathrm{C}$ $\sim 1150^{\circ} \mathrm{C}$ に加熱されている為ての样な粗い組 織を示し硬度が低くなつているものである。

写真 15.16 は鋼種 $\mathrm{A}$ の傘部及び平行部の顕 镜鏡組織を示す。

てれらの材料を再熱処理 $\left(1000^{\circ} \mathrm{C} \times 15\right.$ 分空 冷. $780^{\circ} \mathrm{C} \times 15$ 時間連続時効）した結果平行部 の $\boldsymbol{\sigma}$ 粒な相当大きくなり， $\boldsymbol{\sigma}$ 粒間の距傩も大 となり,ファイパー組織は可成り改良されてい ろ. 傘部の組織は再熱好理前と殆んど変化ない が鋼種 $\mathrm{E}$ 亿於ては $\sigma$ 量が多くなり平行部と大 差なくなつている。再熱処理により鋼種 $A, D$, $\mathrm{E}$ 共傘, 部平行部の組織が均一化されている.

写真 17. 18は鋼種 $\mathrm{A}$ 再熱処理後の傘部平行
部の顕微鏡組織を示す。

（5）時効硬度に及ぼす焼入の有無及び時 効方法の影響

成形後 $740 \sim 780^{\circ} \mathrm{C}$ 亿延へ 15 時間断続時効 した際鋼種 $\mathrm{A}, \mathrm{D}, \mathrm{E}$ の硬度か： $1000^{\circ} \mathrm{C} \times 15$ 分空 冷後 $780^{\circ} \mathrm{C} \times 15$ 時間連続時効（以下標準熱処理 と呼ぶ）したもの〉それに比して約 RC5 程高 くなつた．てれは時效前の焼入の有無, 時効方 法, 時効温度等の熱処理の相違による組織変化 に基因するものと思われるので，との現象を明 らかにする為に次に示す 6 種の熱処理を行い硬 度測定, 組織観察を行つた。

熱処理方法；

\begin{tabular}{|c|c|c|c|c|c|}
\hline \multirow{2}{*}{\multicolumn{3}{|c|}{$\begin{array}{c}\text { 入 狫 } \\
1000^{\circ} \mathrm{C} \times 15 \text { 分空冷 }\end{array}$}} & \multicolumn{3}{|c|}{ 効 } \\
\hline & & & $780^{\circ} \mathrm{C} \times 1$ & 6時間 & 連続 \\
\hline & $"$ & & " & " & 断続 \\
\hline & $"$ & & $750^{\circ} \mathrm{C} \times$ & " & " \\
\hline 压 & 延 & 状 態 & $780^{\circ} \mathrm{C} \times$ & " & 連続 \\
\hline & " & & " & " & 断㓍 \\
\hline & "? & & $750^{\circ} \mathrm{C} \times$ & " & " \\
\hline
\end{tabular}

$\mathrm{KMnO}_{4}$ の $\mathrm{NaOH}$ 溶液によつて電解蝕 $6 \mathrm{~V}, 0.5 \mathrm{~A} / \mathrm{cm}^{2}, 10$ 秒 : 倍率 $\times 1000$ 黒色-carbide 灰色-sigma 地一austenite+ferrite

A

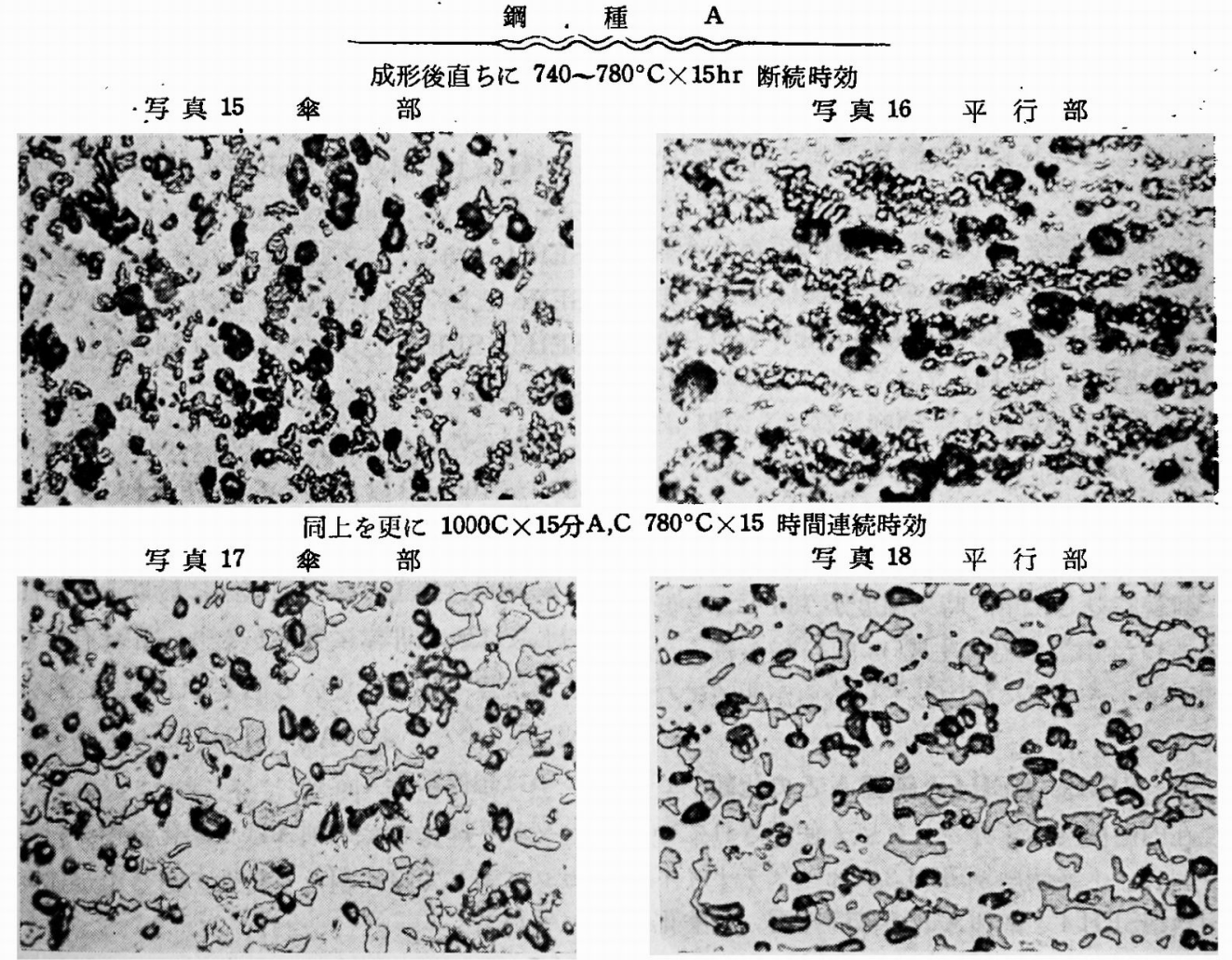




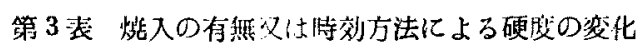

\begin{tabular}{|c|c|c|c|c|c|c|}
\hline \multirow{3}{*}{$\begin{array}{l}\text { 鎆 } \\
\text { 種 }\end{array}$} & \multicolumn{3}{|c|}{ 硬 } & \multicolumn{3}{|c|}{ (Rc) } \\
\hline & \multicolumn{3}{|c|}{$1000^{\circ} \mathrm{C} \therefore 15^{\prime} \mathrm{A}, \mathrm{C}^{\prime}$} & \multicolumn{3}{|c|}{ 王延状態のま〉 } \\
\hline & $\begin{array}{c}780^{\circ} \mathrm{C} \\
\times 15 \mathrm{hr} \\
\text { 連壳時效 }\end{array}$ & 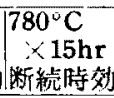 & $\begin{array}{l}750^{\circ} \mathrm{C} \\
\times 15 \mathrm{hr} \\
1\end{array}$ & $\begin{array}{l}780^{\circ} \mathrm{C} \\
\times 15 \mathrm{hr} \\
\times 1 \text { 結侍效 }\end{array}$ & {$\left[\begin{array}{l}780^{\circ} \mathrm{C} \\
\times 15 \mathrm{hr} \\
\times 15 \%\end{array}\right.$} & $\begin{array}{c}750^{\circ} \mathrm{C} \\
\times 15 \mathrm{hr} \\
\times 1{ }^{2}\end{array}$ \\
\hline $\mathbf{A}$ & 39.3 & 39.5 & 39.1 & 41.6 & 42.5 & 44.0 \\
\hline $\mathbf{B}$ & 38.9 & 38.5 & 35.2 & 40.9 & 40.6 & 42.1 \\
\hline $\mathrm{C}$ & 38.8 & 37.3 & 36.2 & 36.7 & 38.4 & 39.1 \\
\hline $\mathrm{D}$ & 39.8 & 41.6 & 38.8 & 42.0 & 44.6 & 44.3 \\
\hline $\mathbf{E}$ & 40.0 & 40.5 & 38.1 & 44.3 & 44.3 & 45.1 \\
\hline
\end{tabular}

各処理传の硬度测定結果第3 表!ニ小け。

硬度に最も大きな影悲を及汪す要因は焼人の 有無である、愤入迈理を行つたものは時刘条件 の変化による影㱖が台んど舆く全般に硬度が低 i.

とれに反し在延のまっ時父したるのは一般に 硬度高く又時郊条件によつて変化する，鍴種 $\mathrm{A}$ は $750^{\circ} \mathrm{C}$ 断続時効の場合に最高硬度 $\left(\mathrm{HR}_{\mathrm{C}}\right.$ 44.0)を示すか $780^{\circ} \mathrm{C}$ 時㕮心埸台は比較的低い.

錭種Dは $780^{\circ} \mathrm{C}$ 及び $750^{\circ} \mathrm{C}$ 断続時効の場合に沙 硬度を示す．鋼種 $\mathrm{E}$ は時效条件の如何に拘らず 高硬度を示す。以上: 3 鋼種の硬度は何机当標準 熱処理のものに比較して約 RC5 高くなつてい 3.

次に組織を観祭した結果同一銅種であれば熱 処理条件が変化しても $\sigma$ 析出量には殆んど相 違は䒜い，即ち硬度の高いもの低いものも析 出 $\sigma$ の総量は大休同しであるか，ての析出状 憼が著しく異つており，硬度の间いの程 $\sigma$ 粒汃絊く $\sigma$ 粒間の距離が近くなつている。

これるり成形バルブの平行部の硬度が標準処 理後の硬度より高いのは压延状態で時効した


目であつた事等の為に生成 $\sigma$ 相の粒が細く, 粒間距嵟が近い哥に起因している哥が明暸にな つた.

\section{IISEH3，SEH4 と鋼程 A との比較}

現在内燃機関排気弁として広く使用されてい るフエライト系耐熱銅SEH 3，オーステナイト 系面熱鎆SEH 4 と銅種 $\mathrm{A} の$ 機械的性質，而酸化
第12図 XCR (A), SEH4 及び SEH3



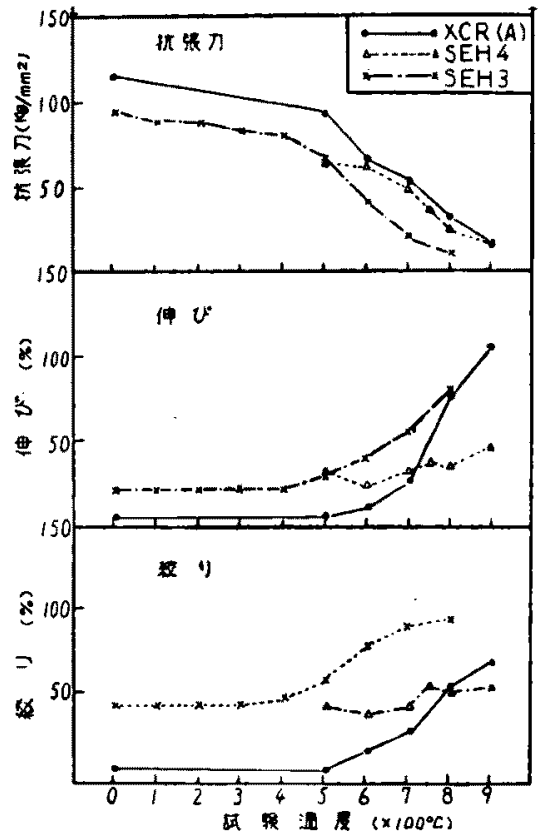

幽について比較を行つた。

第12図はこれら 3 䤡種の熱間に於ける機械的 性賈(8) を示す，抗張力は常温高盜を問わず䤡種 Aが SEH 3 は勿論 SEH 4 よりも優れている. $700^{\circ} \mathrm{C}$ 以上の温度では $\mathrm{SEH} 302 \sim 3$ 倍の強度 を有している，伸びは $800^{\circ} \mathrm{C}$ 以上の温度では $\mathrm{SEH} 4$ より名大で 2 倍以上であり，800 $\mathrm{C}$ で $\mathrm{SEH} 3$ と略々同等である。絞りは $700^{\circ} \mathrm{C}$ 迄は $\mathrm{SEH} 3, \mathrm{SEH} 4$ より小であるが $800^{\circ} \mathrm{C}$ 以上では $\mathrm{SEH4}$ よりも大となつている.

耐酸化性は第 8 図に示す如く $800^{\circ} \mathrm{C}$ ては大美 ないが $1000^{\circ} \mathrm{C}$ 以上になると $\mathrm{SEH} 4$ の酸化增量 は激增し格段の差が諗められる。

又高温含硫黄オ゙ ス雾田気中に於ける酎蝕生に 対して $\mathrm{Cr}$ は非常に効果があり， $\mathrm{Ni}$ は有害であ る事は良く知られている事実であり，とれより $\mathrm{Ni}$ 量の少ない鋼種 $\mathrm{Aが} \mathrm{SEH} 4$ よりも勝つてい る事は想像に難くない。

文献(7)によれば銅種Aは又鉛化合物を含んだ ガスに著しく良く耐える特性のある事が述べら れている。 
以上述バた如く非気弁乞して鋼種Aは语温抗 張力, 伸び, 紋り, 耐酸化性, 槀温含硫黄ガス に対する耐蝕性等们机の点から考えても SEH4 より留秀であり， SEH3 との比較でも伸び絞り は出亏が熟間抗張力, 耐酸化性の著しい優越性 は多少の靶性の出下を補つて充分余りあるもの と考学られる。

\section{IV 総括}

1. 銅種 A.D.Eは加工温度に於て $\alpha+\gamma の$ 混 合組織となる為熱間加工が稍困難であり欠陌 を生じ易いから充分注意を要する。

2.銓塊頭部のマクロ組織は $\mathrm{A}, \mathrm{D}, \mathrm{E}$ 䒔良好で 特に上が優秀である。

3、破面粒度は各鋼種共微細で非金属介在物导 一般に良好である。

4. $1000^{\circ} \mathrm{C}$ 焼入後銅種 A, D, E に於ては 700 $900^{\circ} \mathrm{C}$ の時効で $\sigma$ 相を生成し， $800^{\circ} \mathrm{C}$ に於て 生成量が最に多い，鎆種 Bは $800^{\circ} \mathrm{C}$ の時効で 僅加に。生成方るつで其の他の時効温 度では全然の走析出しない，鋼種Cは何れ の時効温度に於ても全然 $\sigma$ を析出しない。 従つて $\sigma$ 相析出硬化型バルブ 鋼しては踊種 $\mathrm{A}, \mathrm{D}, \mathrm{E}$ が適する。

5，。相の生成は $\mathrm{Cr}$ 量により大きさ影猳を受 け20\% $\mathrm{Cr}$ 以下の鋼に於ては $\sigma$ は全然析出し ない，又Cr 量 $23 \%$ 以上の皆合はC D減量及 びV.Nの添加により $a$ 相生成に人觉は認めら れるい.

6. 時効温度 $780^{\circ} \mathrm{C}$ では鎆種 $\mathrm{A}, \mathrm{D}, \mathrm{E}$ は 15 時 間迄急激な硬度增加を示し20時間で飽利值に 達しそれ以上長時閒になつても余り增加しな い. この硬化現象は $\sigma$ 析出量に比例すると共 に $\sigma$ 粒間の距離が近い程大となる。鎆㮔 $\mathrm{B} む$ 上記三鋼種と同様な傾们を示すが硬化量は午: 般的に少ない，銅種Cは全然異つた性格を示
し時閒の変化による硬度の増诚は認められな い.

7. 鎆稉 $A, D, E$ 络高温に於て 極めて大なる抗 張力を有し伸で，校りも $800^{\circ} \mathrm{C}$ 以上では良好 である。

8. 衝撃試験は鋼種Aにーついてのみ行つたが, その常温及び熱間衝摮值は余り良好でない.

9.各鋼種共 $800^{\circ} \mathrm{C}$ ばは充分なる酎酸化性を示 すが $1000^{\circ} \mathrm{C}$ 以上では低 $\mathrm{Cr}$ 及び合 $\mathrm{V}$ 鎆の耐酸 化性が稍少る。

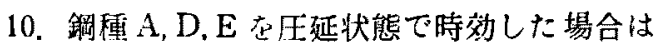
焼入後時効した星合に比して $\sigma$ 相の析出量で は大差ないが，。粒が微細で粒䦎距離が近い 為硬度加高い。

11. 富士バルブ K. K に於て自動車用排気弁を 試作した結果製造に特に困難は認められず鈠 造性はSEH4よりも容易である。

アプセット時の加熱により䏑部々平行部に 著しい硬度差を生ずるけれども鋂造後再焼入 する事により両者の硬度は均一化される。

12,鋼種 $\mathrm{A}$ は SEH4よりも高温に於ける機械的 性質，耐酸化性が優秀である。

釉りに本研究の実用試騃に対し御坛力下つ た富士バルブ K. K 筒井正寿氏に深く感謝の 意を表します。

以上.

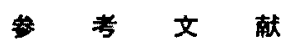

(1) Automotive Industries, (1955) June, p. 52

(2) Jessop社型録Special Alloy \& Tool Steels p. 92

(3) Werkstoff-Handbuch Stahl und Eisen 1953

(4) Jahn J. Gilman : Trans of A.S.M Vol XLIII 1951 p. 161

(5) John J. Gilman: Preprint of A. S.M 1951

(6) 小柴：特殊悀 p. 209, p. 213

（7）森岡：金風防触技術総婜 上巻 p. 186 